\title{
A MISKOLCI EGYETEM LOGISZTIKAI INTÉZETÉBE TELEPÍTETT HIGH-TECH LOGISZTIKAI LABORATÓRIUM BEMUTATÁSA
}

\author{
Károly Máté \\ logisztikai mérnök BSc hallgató, Miskolci Egyetem \\ Logisztikai Intézet
}

3515 Miskolc, Miskolc-Egyetemváros, e-mail: karaj96@me.com

Veres Péter

tanársegéd, Miskolci Egyetem

Logisztikai Intézet

3515 Miskolc, Miskolc-Egyetemváros, e-mail: altveres@uni-miskolc.hu

\author{
Skapinyecz Róbert \\ egyetemi adjunktus, Miskolci Egyetem \\ Logisztikai Intézet \\ 3515 Miskolc, Miskolc-Egyetemváros, e-mail: altskapi@uni-miskolc.hu
}

\begin{abstract}
Absztrakt
A Miskolci Egyetem Logisztikai Intézetének High-Tech Logisztikai Laboratóriuma a közelmúltban alapos változáson esett át. Nem csak a helyszine változott meg, hanem a felépitése és integráltsága is. Az áttelepités során figyelembe vettük a helyi adottságokat, amellyel, a rendszer sokkal kompaktabb lett. Emellett az átszervezés során lehetőségünk nyilt a teljes rendszert felülvizsgálni. Felkértünk egy fejlesztö csapatot és segitségükkel kibövitettük a rendszert olyan funkciókkal, amelyek már a mai kor elveit képviselik. A dolgozatban elöször a laboratórium alrendszereit szeretnénk ismertetni, miközben létesitmény által nyújtott egyedi oktatási és kutatási lehetöségeket is bemutatjuk. Ismertetjük a rendszer néhány lehetséges jövöbeli frissitését is, a logisztikai automatizálás legújabb fejlesztéseivel összhangban. Úgy gondoljuk, hogy ezek a betekintések számos jelenlegi és jövöbeni szakember számára hasznosak lehetnek, akiket érdekel az automatizálás jelenlegi állása a logisztika területén.
\end{abstract}

Kulcsszavak: automatizálás, integrált anyagmozgató rendszer, oktató laboratórium

\begin{abstract}
The High-Tech Logistics Laboratory of the Institute of Logistics at the University of Miskolc has undergone a major change recently. It has changed its location and also its structure and integration. The system got a new compact form that fits the capabilities of the new location. In addition, the reorganization allows for a complete systematic review and hiring a development team for and expanding the system's capabilities and automatic functions, that can represents the principles of today. In this paper, we would like to describe the subsystems of the laboratory while showing the opportunity of teaching and research themes. In addition, we would like to introduce the possibility of the system upgrades, which can be occurring in the near future in the field of logistics automation. These aspects can be useful to current and future professionals, who are interested in the state of automation in logistics.
\end{abstract}

Keywords: automated material handling, integrated material handling system, training lab 


\section{Bevezetés}

Noha az automatizálás szerepe a logisztika és az anyagmozgatás területén egyre fontosabbá vált az elmúlt néhány évtizedben, valószínüleg még soha nem volt ilyen fontos, mint ma. Az Ipar 4.0 alapelvek egyre növekvő átvételével és felhasználásával a legtöbb ipari ágazatban döntő fontosságúvá vált a kapcsolódó logisztikai folyamatok automatizálása egy teljesen új szinten is $[1,2]$. Ezek az elvek és az ipari késztetés adta meg a löketet arra, hogy a már létező logisztikai laboratóriumunkat teljesen újragondoljuk és a már meg lévő elemekből építkezve egy jobb és hatásosabb rendszer építsünk fel, amellyel reprezentálni tudjuk az iparban használatos módszereket és hatékonyabbá tegyük az oktatást.

A jelenlegi formájában a laboratóriumot 2018-ban telepítették át az intézetünk épültébe. Miközben a jelenlegi rendszer számos alrendszert örökölt az előző iterációkból (például a palettázó állomást) a legtöbb alkotóeleme az iparban ma is használatos elemből áll vagy egyedileg a saját igényekre fejlesztett eszközöket használ. A következőkben ezeket az alrendszereket fogjuk bemutatni oktatási, kutatási és fejlesztési oldalról is.

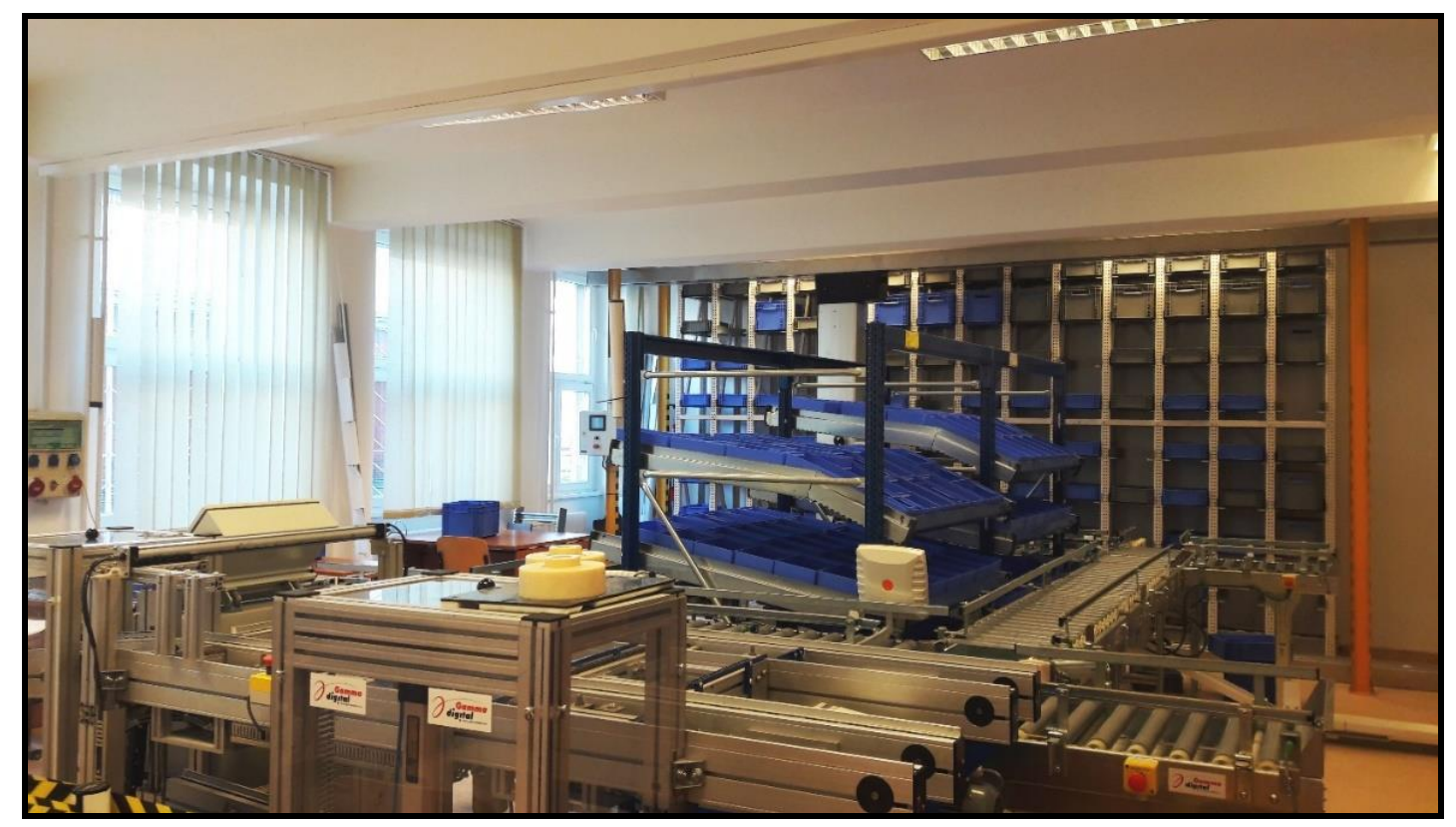

1. ábra: A High-Tech laboratórium jelenlegi elrendezése

\section{A High-Tech Logisztikai laboratórium alrendszerei}

A Logisztikai Intézet High-Tech logisztikai laboratóriumának központi része egy integrált anyagmozgató rendszer, amely a következő fö alkotóelemeket tartalmazza: PLC vezérelt görgős szállítószalag, amely a teljes rendszer gerincét képezi; palettázó állomás; és egy automatizált tárolórendszer. Ezeknek az alkatrészeknek az általános elrendezése látható az 1. ábrán.

Emellett kiemelném, hogy noha az 1. ábrán nem látható, de a rendszert egy automatikusan vezérelt jármü (AGV) egészíti ki. Erről az egységről később alaposabban beszámolunk. 
A rendszer központi alkotóeleme a görgös pálya rendszer, amely alapvetően összeköti a komponenseket. Ezt majdnem az összes ábrán megfigyelhetjük. A szállítórendszer több modulból áll, amelyek mind külön elektromos hajtással és vezérléssel rendelkeznek. Az egyenes szakaszok 2-4 méteres modulokból állnak, optikai szenzorokkal felszerelve, amelyek információt gyüjtenek elsősorban a rajtuk közlekedő árukról, amelyeket pneumatikus müködtetésủ blokklemezekkel forgalomtól függően képesek vagyunk megállítani (torlasztani) és indítani. Útkereszteződéseknél forgatóasztal, vagy átemelö berendezés továbbítja az árut a megfelelő irányba. Ezek az elemek szintén elektro-pneumatikus elven müködnek, amelyek müködéséröl egy ipari kompresszor gondoskodik. A 2. ábrán ezen elemek mellett még látható egy pneumatikus ládarögzítö, melynek feladata, hogy egy helyben tartsa a ládát, amíg a benne lévő dolgokkal vagy egy ember vagy egy robot müveletet végez. Továbbá a 2 . ábrán még látható egy fehér négyzet a fordítóasztal fölött, ami egy RFID olvasó, amely képes az elötte elhaladó chippel felszerelt termékeket (akár 100-at is egyszerre) azonosítani, anélkül hogy látná vagy manipulálná azokat. A szállítópálya több ponton is fel van szerelve ezekkel az eszközökkel.

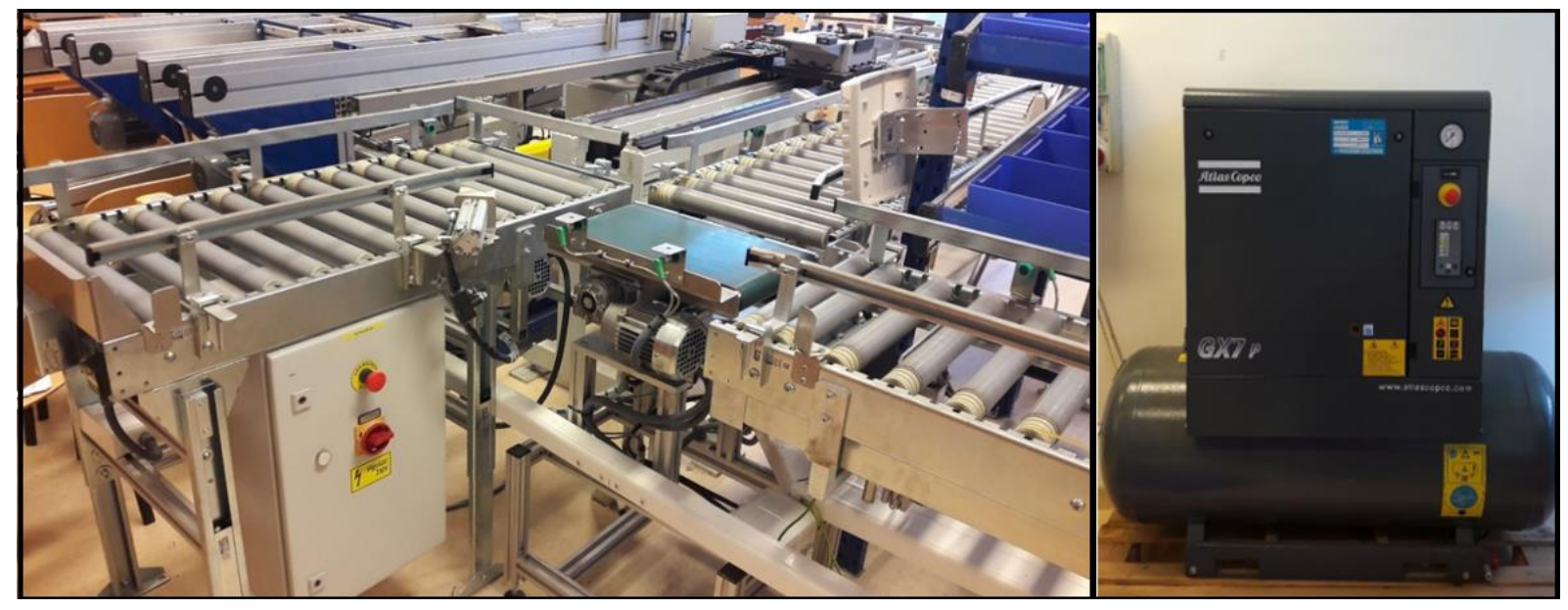

2. ábra: Balra: Görgöspálya forditóasztallal, Jobbra: Ipari kompresszor

A görgöspályarendszert körülöleli egy gravitációs tároló állványrendszer (kék dobozok ferde polcon), amely egy manuálisan (kézi erővel) müködtetett magától utántöltésre képes tároló, ezzel az emberi munkahelyet és munkavégzést tudjuk reprezentálni egy automatizált rendszeren belül vagy mellett. Ez a rész teljes egészében a 3. ábrán tekinthető meg:

A görgöspálya egy automatikus tárolórendszerhez van csatlakoztatva a laboratórium hátsó részében. A magasraktári tárolásra alkalmas polcrendszer egy ipari mintára készült egyedi rendszer. Ezek a polcrendszerek a valóságban 15 métertől is magasabbak lehetnek, ezért nálunk az alacsony belmagasság miatt egyedi készítésủ eszközöket kellett alkalmazni. A polcrendszert egy automatikus felrakógép szolgálja ki, amely előprogramozással tudja az állványon lévő egyes tárolóhelyek pontos helyét, amelyeket optikai érzékelőkkel határoz meg, mellyel távolságot mér. A gép képes az automatikus müködésre is, a rendszer közli, melyik helyről kell kivennie egy adott dobozt, vagy melyik helyre kell berakodnia. A felrakógép közvetlen kapcsolatban áll a görgőspálya rendszerrel és képes kiszolgálni azt. A 4. ábra a felrakógépről és a magasraktár jellegü tárolóról készült müködés közben: 


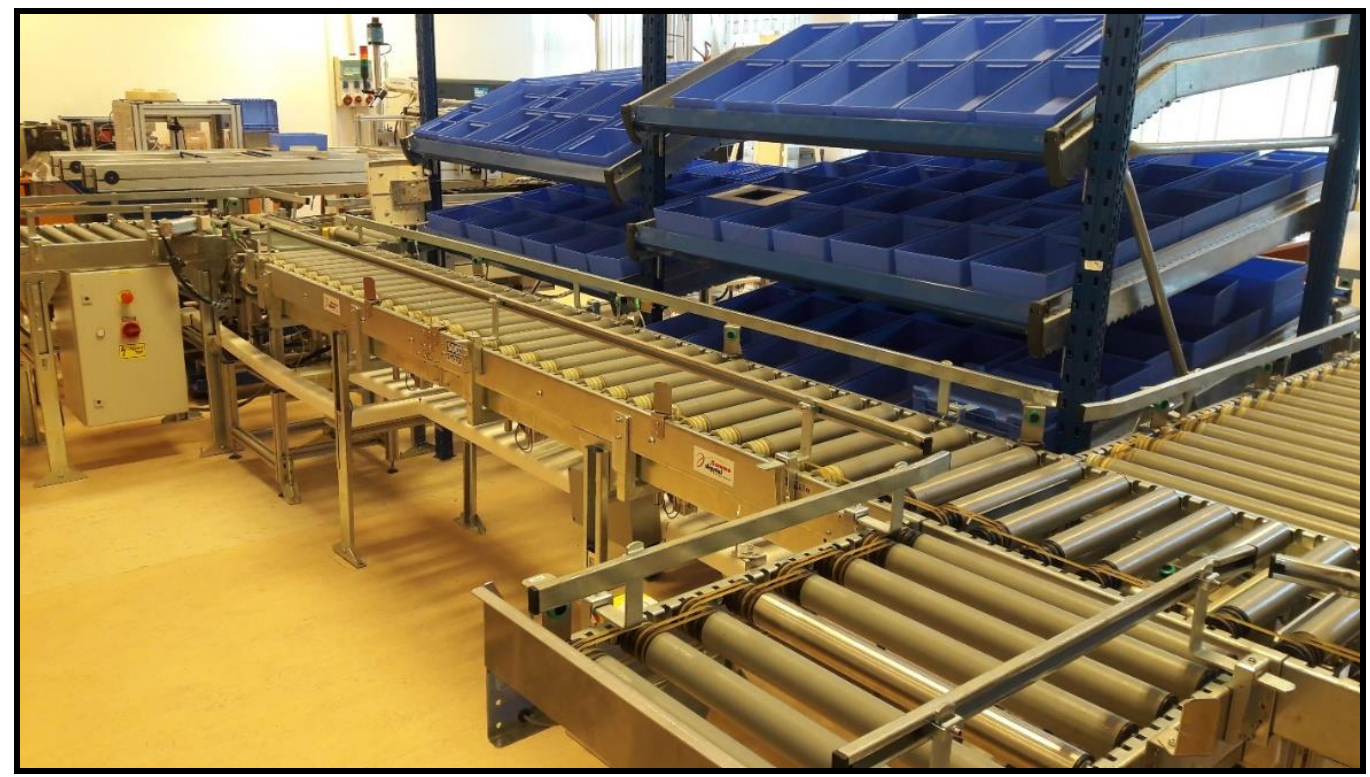

\section{3. ábra: Gravitációs tárolóállvány}

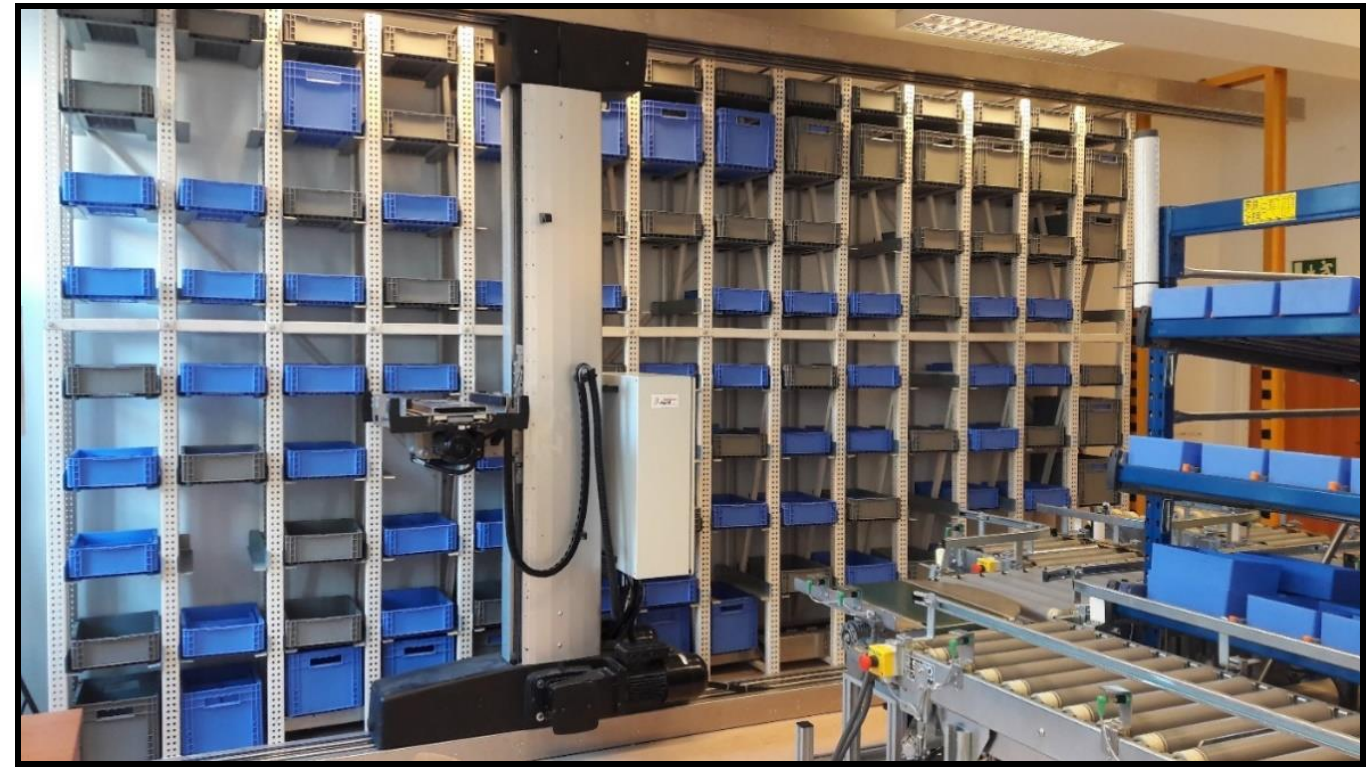

4. ábra: Polcrendszer, felrakógép és csatlakozás a fö rendszerhez

Fontos megjegyezni, hogy előzőekben leírt komponensek együttesen és automatikusan müködtethetők egy PLC-alapú vezérlőegységgel, azonban mindegyik alrendszer el van látva külön vezérlőegységgel is, hogy akár önállóan is müködjön. A PLC-alapú vezérlőegységgel tudjuk automatikusan és manuális is müködtetni a különböző egységeket a kijelzőjén keresztül, ami egyben egy érintő képernyö. Bár a kézi müködtetés opció, természetesen a rendszer valódi erőssége az, hogy integráltan auto- 
nóm módon müködhet. Ez azt jelenti, hogy a leírt komponensek emberi beavatkozás nélkül cserélhetnek dobozokat egymás között (természetesen, kivéve a középső kézi tároló állványt), miközben a rendszer összetett anyagkezelési stratégiákat is képes végrehajtani. Ezt lehetővé teszi az érzékelők intenzív felhasználása a teljes rendszerben. Az Ipar 4.0 megoldások intelligens érzékelőkön és szenzorhálózatokon alapulnak, és nagy hatással vannak a kiber-fizikai rendszerek teljesítményére, megbízhatóságára és hatékonyságára, különösen összetett, hálózatszerüen müködő ellátási láncok esetén, de akár a közvetett ellátásban és a crossdocking megoldásokban is. [3]. Erre szolgál jelen esetben a rendszerbe épített hagyományos SCADA (felügyeleti vezérlés és adatgyüjtés) rendszer, valamint a legkorszerübb MES (gyártás-végrehajtási rendszer) szintén, ezáltal lehetővé téve a teljes rendszer magasabb szintủ ellenőrzési stratégiáinak megvalósítását. Emellett az Ipar 4.0 egy másik eszköze is megfigyelhető benne, ami a digitális iker, amellyel az egész rendszert láthatjuk müködés közben és vizsgálhatjuk a tulajdonságait és paramétereit, anélkül hogy fizikailag közbe kellene avatkoznunk [4].

Mint már korábban említettük, a rendszer részét képezi egy automatikusan vezérelt jármü (AGV), amely még rugalmasabb módot kínál az egyes dobozok mozgatására a laboratóriumban. Ez a jármü lézerradarral van felszerelve, egy modern és gyakran használt megoldással az autonóm jármüvek helymeghatározására. Ami ezt az AGV-t azonban igazán egyedivé teszi, az, hogy fel van szerelve egy kompakt Mitsubishi robotkarral, ezért az elöre meghatározott feladatnak megfelelően képes manipulálni a szállított dobozokban lévő árut is. Az 5. ábrán lévő AGV áll jelenleg a legnagyobb fejlesztések és kutatások alatt, ami nem meglepő, ugyanis az automatikusan vezérelt jármüvek nem csak az iparban, de már a személy és árú szállításban is a figyelem középpontjába kerültek.

Ezek az AGV-k adják meg az alapot egy olyan költséghatékony egyedi gyártás megvalósításában, ahol a teljes gyártási és anyagszállítási rendszer rugalmasan viselkedik. Egy ilyen rendszert azonban normál eszközökkel nem lehet tervezni és irányítani, viszont magas szintü szimuláció segítségével képesek vagyunk optimálisan müködtetni [5].

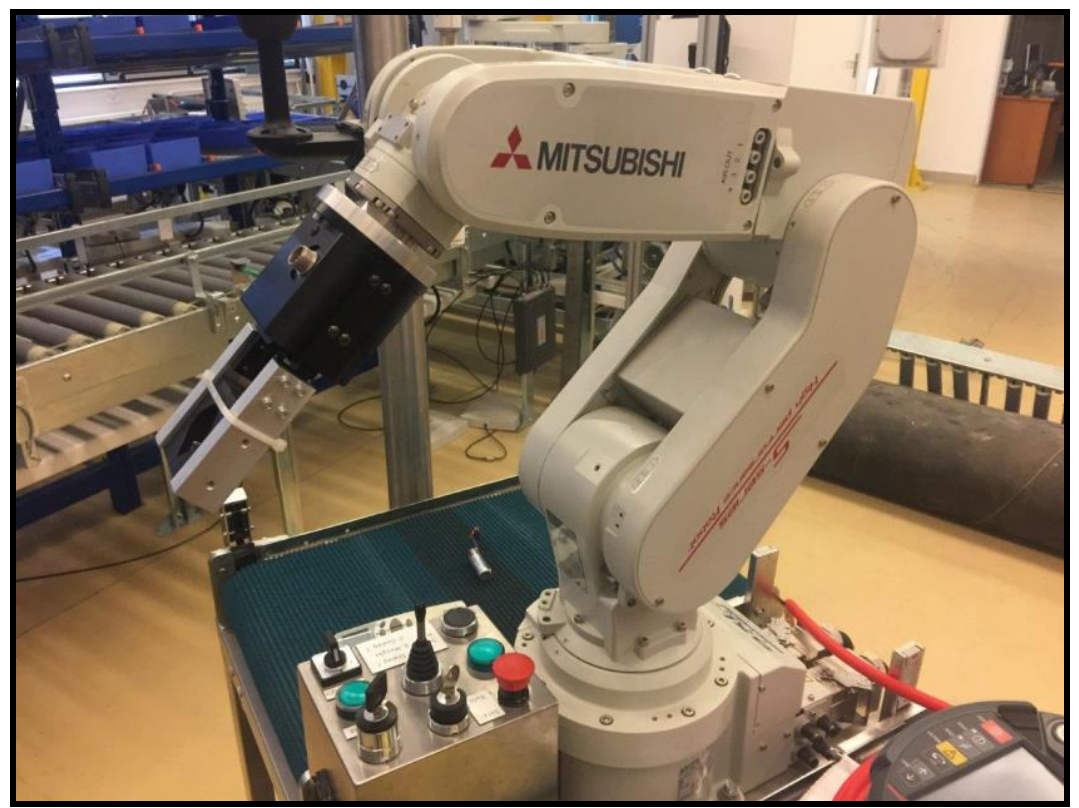

5. ábra: $A G V$ robotkarral felszerelve 


\section{Kutatási és fejlesztési lehetőségek a laborban}

Amint az a laboratórium és alrendszereinek leírásából is kitünik a komplett, integrált anyagmozgató rendszer alkalmas az Ipar 4.0 koncepcióhoz kapcsolódó kutatási szerep betöltésére. Egy példa lehet erre a nagymennyiségü adatelemzési technikák (Big Data) alkalmazása a rendszeren keresztül összegyüjtött különféle információk feldolgozására. Az adat a korábban említett érzékelőktől (optikai érzékelők és RFID olvasók), a PLC-alapú vezérlőegységből, az automatizált tárolórendszerből, az automatikusan vezetett jármüből és a palettázó állomástól származik. Fontos megjegyezni, hogy maguk a vezérlő PLC-k szintén nagy mennyiségü adatot gyüjtnek, például a légnyomásról, a hajtómotor állapotáról, csak hogy néhányat említsünk.

A gyüjtött és elemzett adatok felhasználása többféle módon is történhet. Jellemző alkalmazása az egyes gépelemek, elsősorban a görgőspálya hengereinek, meghibásodásának pontos előrejelzése a gördülési tényező, a szállítási teljesítmény és a motorterhelési jellemzőinek függvényében. Erre számtalan példát lehet látni az iparban, mivel a hengerek kopása tipikus gyengesége a nagyméretủ szállítórendszereknek. Ezen kívül a szállítórendszerek teljesítményének mérése lehetővé teszi a részletes energiahatékonysági elemzést is. Ez azért fontos, mert manapság a legkorszerübb technológiai megoldások energiahatékonysága nem csak a gyártást befolyásolja, hanem a gyártással kapcsolatos logisztikai és ellátási láncok egyik legfontosabb tényezője is, beleértve a technológiai és humán erőforrásokat. [6] Ezen kívül az ilyen típusú elemzések hasznosnak bizonyulhatnak a logisztikai rendszerek minőségirányításában is, különösen mivel segítenek a rendszerek meghibásodásainak és hibáinak előrejelzésében [7].

Mint már említettük, az AGV-vel kapcsolatos kutatásoknak jelenleg óriási jelentőségük van az iparra és közlekedésre nézve. A mi önjáró targoncánkkal két fő kutatási irányt reprezentálhatunk: Az autonóm müködés fejlesztését vagy a gyártáson belüli rugalmas anyagszállítási megoldásokat. A jármü jelenleg is folyamatos fejlesztés alatt áll mindkét területen és aktívan használja a rá szerelt robot kart is. Rugalmasan berakhatja és kirakhatja a rakományt a szállítórendszer erre kialakított pontjain miközben a manipulátor karja előre programozott feladatokat (finising müveletek, komissiózás, stb) is elvégezhet. Mindazonáltal rengeteg fejlesztési lehetőség is felmerül, különös tekintettel a mesterséges intelligencia terén, amely mind az automatikus müködéshez, mind a logisztikai rendszer optimális kiszolgáláshoz kapcsolódhat. Egy másik releváns kutatási terület az ember-gép ipari kapcsolat kialakítása és egymás melletti biztonságos müködés megalkotása. Természetesen a manipulátor kar együttmüködési képességeit a jövőben is javíthatjuk, mivel ez fontos kutatási terület lehet az Ipar 4.0-ban.

A fejlesztés újabb iránya lehet a laboratórium további robotizálása, tekintettel arra, hogy intézetünknek már van Kuka KR 5 Sixx sorozatú ipari robotja, amely jelenleg áthelyezés alatt áll. Ez a robotkar integrálható lehet a görgőspályarendszer valamelyik pontjára, ahol komissiózó vagy megmunkáló feladatokat láthat el. Egy másik érdekes terület lehet e robot kooperációja az AGV-vel és annak robotkarjával. A közös együttmüködési feladatok lehetnek például a dobozok rakományokkal történő be- és kirakodása, amely természetesen magában foglalja a válogatási feladatokat is. Természetesen az ilyen fejlett képességekhez ebben az esetben valószínüleg további szenzorok használata is szükség lenne. 


\section{Oktatás a laboratóriumban}

A bemutatott laboratórium és annak integrált anyagmozgató rendszere számos oktatási lehetőséget kínál. A laboratóriumban megtalálható különféle technológiák és megoldások megismerésével a hallgatók értékes ismereteket szerezhetnek különféle területeken. Elsősorban betekintést nyernek a logisztikai rendszerek tervezésébe, az Ipar 4.0 alapelveit felhasználva. Tanulmányozhatják és megfigyelhetik a különféle anyagmozgatási stratégiák valós rendszerben való megvalósítását, mint például a SMED (Single-minute exchange of die) módszer, amely tipikus stratégiai eszköz a karcsúsított gyártásban és a logisztikában [6]. Ezen kívül a hallgatók megismerkedhetnek a logisztikai megoldások többségével, amelyeket az iparban is használt anyagmozgató rendszerekben is alkalmaznak. Emellett gyakorlati ismereteket szerezhetnek számos olyan területen is, amely közvetlenül kapcsolódik az automatizált anyagmozgatáshoz, például az alkalmazott informatika egyes területein (robot és PLC programozás), az automatizálás bizonyos területein, az elektrotechnika egyes alterületein és a mechatronika területén. Itt is fontos megjegyezni, hogy Intézetünk több oktatási programot müködtet, amelyekben a laboratórium fontos szerepet játszik. Ide tartoznak a BSc és az MSc logisztikai mérnöki oktatási programjaink, valamint a lean folyamatmérnöki képzési programunk, nem is beszélve a tervezett Industry 4.0 folyamatmérnöki programról. Végül, a laboratórium természetesen fontos szerepet játszik $\mathrm{PhD}$ hallgatóink képzésében és kutatási tevékenységében is.

\section{5. Összegzés}

A dolgozatban részletes bemutatjuk a Miskolci Egyetem Logisztikai Intézetének High-Tech Logisztikai Laboratóriumát és megvitatjuk a különböző kutatási és oktatási és fejlesztési lehetőségeit. Ennek az áttekintésnek az volt a célja, hogy bemutassa a legkorszerübb anyagmozgató rendszer különféle alkalmazását, különös tekintettel az Ipar 4.0 koncepció szempontjából. A rendszerben használhatók és bemutathatók olyan iparban is használt módszerek, mint a BigData alapú elemzések, a digitális iker koncepciója vagy az ember-gép kooperáció alapjai, melyhez jelenleg egy fejlett AGV és későbbiekben remélhetőleg egy ipari Kuka robot is hozzájárul majd. Az integrált anyagmozgató rendszer szintén jó alapul szolgál a jövőbeni mérnökök oktatásához, ugyanakkor különféle kutatási lehetőségeket kínál a fiatal kutatók számára. Laboratóriumunk átfogó képet nyújt a különféle Ipar 4.0 megoldásokról. Ez hasznos kiindulási pontként szolgálhat minden olyan kutató, jelenlegi vagy jövöbeni szakember számára, aki érdeklődik az Ipar 4.0 alapú anyagmozgató megoldások és alkalmazások fejlesztése iránt.

\section{Köszönetnyilvánítás}

A cikkben ismertetett kutató munka az EFOP-3.6.1-16-2016-00011 jelü „Fiatalodó és Megújuló Egyetem - Innovatív Tudásváros - a Miskolci Egyetem intelligens szakosodást szolgáló intézményi fejlesztése" projekt részeként - a Széchenyi 2020 keretében - az Európai Unió támogatásával, az Európai Szociális Alap társfinanszírozásával valósul meg. 


\section{Irodalom}

[1] Illés, B., Tamás, P., Dobos, P., \& Skapinyecz, R.: New challenges for quality assurance of manufacturing processes in industry 4.0. Solid State Phenomena 2017, 261, pp.481-486, https://doi.org/10.4028/www.scientific.net/SSP.261.481

[2] Skapinyecz, R., Illés, B., \& Bányai, Á.: Logistic aspects of Industry 4.0. IOP Conference Series: Materials Science and Engineering 2018, 448 No.1, Paper:012014. https://doi.org/10.1088/1757-899X/448/1/012014

[3] Bányai T.: Direct shipment vs. cross docking. Advanced Logistic Systems: Theory and Practice 20126 No.1, pp. 83-88.

[4] Tamás, P.: Examining the possibilities for efficiency improvement of SMED method using simulation modelling. Manufacturing Technology 2017, 17 No.4, pp.592-597.

[5] Tamás, P.: Decision Support Simulation Method for Process Improvement of Intermittent Production Systems, Applied Sciences-Basel 2017, 7 No.9, Paper:950, https://doi.org/10.3390/app7090950

[6] Bányai, T., Landschützer, C., Bányai, Á.: Markov-Chain Simulation-Based Analysis of Human Resource Structure: How Staff Deployment and Staffing Affect Sustainable Human Resource Strategy. Sustainability 2018, 10 No.10, Paper:3692. https://doi.org/10.3390/su10103692

[7] Illés, B., Glistau, E., Machado, N. I. C.: Logistik und Qualitätsmanagement, Miskolc, 2007, ISBN 978-963-87738-1-4. 